\title{
ILLEGAL ABDUCTIONS BY STATE POLICE: SANCTIONS FOR EVASION OF EXTRADITION STATUTES*
}

WhEN a person charged with crime is beyond the jurisdiction of the prosecuting state, its police lack power to bring him back for trial. ${ }^{1}$ To fill this law enforcement gap, extradition statutes set up procedures for delivery of the accused by the state of refuge to the demanding state. ${ }^{2}$ But in practice these procedures are not always observed. ${ }^{3}$ Police, either ignorant of the statutes or impatient with technical delays, have sometimes crossed state lines

*Collins v. Frisbie, 189 F.2d 469 (6th Cir. 1951), cert. grantcd, 20 U.S.L. WEets 3113 (1951).

1. Stears, The Law of Extradition 346-7 (1879).

2. "A person charged in any state with treason, felony, or other crime, who siall flee from justice, and be found in another state, shall on demand of the executive authority of the state from which he fled, be delivered up, to be removed to the state having jurisdiction of the crime" U.S. Const. ART. IV, \$2(2).

Pursuant to this article, federal statutes have been enacted. 18 U.S.C. $\$ \$ 3182,3194$, 3195 (Supp. 1946). These statutes prescribe the procedure for returning a fugitive to a state where a orime is charged against him. The federal statutory requirements must be met before a person can be extradited. Pierce v. Creecy, 210 U.S. 387, 401 (1908); In re Hubbard, 201 N.C. 472, 160 S.E. 569 (1931).

Although the federal law is supreme, states may provide machinery for applying the law of extradition in respect to matters not covered by the acts of Congress. See, c.g., Moore v. Illinois, 14 Howard 12 (U.S. 1852); Ex farfo Morgan, 78 F. Supp. 756 (S.D. Ca1. 1948), aff'd, 175 F.2d 404 (9th Cir, 1949). States have legislated concerning the method of applying for the writ of habeas corpus, the method of arrest and detention of the fugitive before extradition is demanded, the mode of preliminary trial, the means of applying for the requisition, the extent of asylum allowed, and the extraditees" exemption from civil process. The Uniform Criminal Extradition Act, 9 Unir. Laws Ann. 169 (1951) (cited hereafter as Uniform Act), which codifies procedure among the states, has been enacted by 34 states and Hawaii. Sec, c.g., CAL. Perra CoDz $\$ \$ 154 \$-$ 1556.2 (Deering 1949) ; MIICE. Stat. Awas. $\$ \$ 28.1285$ (1)-28.1285(31) (Supp. 1949). See also the extradition statutes of the states which have not adopted the Uniform Act. E.g., WASH. Rev. Stat. ANn. \$\$2241-2246 (Remington 1932).

For general discussion of extradition, see 1 MLORE, Extradition atid InTEsstate Rendition (1891); Hurd, Hareas Corpus (2d ed. 1876).

3. For cases in which courts found that extradition procedure was ignored, sce Mahon v. Justice, 127 U.S. 700 (1888) (accused under indictment in Kentuchy abdueted from West Virginia by a mob led by a state agent); Leahy v. Kunkel, 4 F. Supp. 849 (N.D. Ind. 1933) (Indiana officers seized accused in Chicago after hearing he was there, and forcefully brought him back to the state. The warrant was read to the defendant only after his return); Kingen v. Keeley, 3 Wyo. 566, 28 Pac. 36 (1891) (accused hunted down in Nebraska by Wyoming authorities and forcibly returned). Additional cases in which irregular return was alleged are: Hatfield v. Warden of State Prison, 88 F. Supp. 690 (E.D. Mich. 1948) (prisoner alleged he was kidnaped from Tevas to Michigan by Michigan officials); Jackson v. Olson, 146 Neb. SS5, 22 N.W. $2 d 124$ (1946) (prisoner alleged he was forcibly brought in chains from California to Nebrasla). 
and forcibly removed accused persons. ${ }^{4}$ Occasionally officers of the asylum state cooperate in such evasion of the extradition law.

Abductions by police have generally been carried out with impunity. Courts hold that the manner in which a defendant's presence was sectured does not impair their jurisdiction to try him. ${ }^{6}$ If a defendant was properly indicted and his rights were observed during the trial, he cannot successfully claim a denial of due process on the ground that he was illegally returned from another state. ${ }^{7}$

Departing from prevailing judicial attitudes, the recent case of Collins v. Frisbie ${ }^{8}$ threatens stern consequences if police fail to extradite suspects properly. Collins, indicted for murder in Michigan, was apprehended in Illinois. Ignoring the extradition statutes, Illinois officers allegedly placed him in the custody of police who had come from Michigan. According to Collins, the Michigan officers beat him with blackjacks, threw him in the trunk of an automobile, and thus forcibly returned him to Michigan for trial. Eight years after his conviction, Collins asked a federal court to release him by habeas corpus on the ground that the abduction invalidated his trial. The trial court

4. See Kingen v. Keeley, 3 Wyo. 566, 575, 28 Pac. 36, 39 (1801) (state officers ignored extradition act because of its technical requirements which would delay more prompt return of the fugitives). Note also the actions of the officers in Leahy v. Kunkel, 4 F. Supp. 849 (N.D. Ind. 1933) cited in note 3 supra. Their action can only be attributed to ignorance of the law or impatience with technical delay.

For discussion of causes for police violation of criminal procedure see HopwiNs, Oun Lawless Police 314-47 (1931).

5. See Ex parte Glenn, 103 Fed. 947 (C.C.D. W.Va. 1900) (prison jailer of asylum state illegally aided in turning defendant over to West Virginia authorities); Leahy v. Kunkel, 4 F. Supp. 849 (N.D. Ind. 1933) (Illinois officers cooperated with Indiana officials in removing the defendant from Illinois); see also allegations in Collins $v$. Frisbie, 189 F. 2d 464 (6th Cir. 1951) (cooperation by officials of asylum state to secure abduction of extraditee). See Uniform Act $\S 11$, which prescribes penalties for officers of the asylum state who violate the act.

6. E.g., People v. Klinger, 319 I11. 275, 149 N.E. 799 (1925); State v. Owen, 119 Ore. 15, 244 Pac. 516 (1926). In state habeas corpus proceedings the trial courts' jurisdiction has been upheld even though violence was allegedly committed on the person to secure return. E.g., Jackson v. Olson, 146 Neb. 885, 22 N.W. 2 d 124 (1946). Nor can the person claim as a trial defense the forceful methods utilized to return him. E.g., Wilson v. State, 145 So. 591 (Ala. App. 1933); State v. Day, 58 Iowa 678, 12 N.W. 733 (1882). Only Kansas recognizes illegal seizure and abduction as a valid defense. State v. Simmons, 39 Kan. 262, 18 Pac. 177 (1888). The rationale of the decision was that a state could not tolerate breaches of the peace in sister states by their own police officials.

The federal courts have also followed the general rule that a trial court's jurisdiction is not impaired by the manner in which the defendant was brought into the state. E.g., Lascelles v. Georgia, 148 U.S. 537 (1893); Sheehan v. Huff, 142 F. 2 d 81 (D.C. Cir. 1944). But cf. United States v. Rauscher, 119 U.S. 407 (1886).

7. Kerr v. Illinois, 119 U.S. 436 (1886) ; Hatfield v. Warden, \&\& F. Supp. 690 (E.D. Mich. 1950). Contra: Brown v. Frisbie, 178 F.2d 271 (6th Cir. 1949).

8. 189 F. 2 d 464 (6th Cir. 1951), cert. granted, 20 U.S.L. WeEK 3113 (1951). 
denied the writ. ${ }^{9}$ On appeal, the Sixth Circuit Court of Appeals reversed. It held that Collins' allegations, if proved, showed that police who brought him from Illinois were guilty of kidnaping under the federal Anti-kidnaping (Lindbergh) Act. ${ }^{10}$ Violation of a federal criminal statute, the court declared, could not be the instrument for asserting jurisdiction over criminal defendants. ${ }^{11}$

The Collins decision rests on shaky ground. The Lindbergh Act is limited to cases where the kidnaper seeks some benefit, usually pecuniary. ${ }^{12}$ To hold that police officers' interest in apprehending a fugitive satisfies the statutory requirements seems unduly loose construction, especially when violators of the Act may be punished by death. Moreover, it is doubtful whether the statute, aimed at organized crime, was ever intended to apply to state officials acting under color of law. ${ }^{13} \mathrm{~A}$ further weakness of the Collins holding is that

9. Is re Collins, No. 9086 (E.D. Mich. 1950).

10. "Whoever knowingly transports in interstate or foreign commerce any person who has been unlawfully seized, confined, inveigled, decoyed, lidnaped, abducted, or carried away and held for ransom or reward or otherwise, except, in case of a minor, by a parent thereof, shall be punished (1) by death if the lidnaped person has not bsen liberated unharmed, and if the verdict of the jury shall so recommend, or (2) by imprisonment for any term of years or for life, if the death penalty is not imposed." 18 U.S.C. $\$ 1201$ (Supp. 1946) (popularly known as the Lindbergh Act).

11. Collins v. Frisbie, 189 F. 2d 464, 468 (6th Cir. 1951).

Contrast however the attitude of the Supreme Court toward violation by the state officers of the prohibition against illegal searches and seizures. Though conceding that such searches and seizures violate the 14th Amendment and perhaps the Civil Rights Act, Rev. Stat. $\$ 1979$ (1875), S U.S.C. $\$ 43$ (1946), the court refuses to apply federal sanctions against such conduct. Stefanelli et al. v. Minard et al., 72 Sup. Ct. 118 (1951); Wolf v. Colorado, 338 U.S. 25 (1949).

12. The kidnaping statute, 18 U.S.C. $\$ 1201$ (Supp. 1946), expressly states the person abducted must be held for ransom or reward or otherwise. However the courts have held that 'otherwise' may include any benefits which may accrue to the violator of the act, and does not restrict kidnaping to cases involving pecuniary benefit to the abductors. Gooch v. United States, 297 U.S. 124 (1936) (state officers abducted by fugitives to avoid arrest) ; Poindexter v. United States, 139 F. 2d 158 (Sth Cir. 1943) (rape was purpose of abduction); United States v. Parker, 103 F.2d 857 (3d Cir. 1939) (private person abducted another to elicit a confession of crime); United States v. Cleveland, 146 F. 2d 730 (10th Cir. 1945) (girl transported across state line for immoral purposes). This interpretation brings the federal statute close to the common law crime of kidnaping under which no benefit is required. See $4 \mathrm{BL}$. Corss. $* 219$.

13. The Collins case marks the first time that the Lindbergh Act has been applied to police officials acting under the color of law. In Chatwin v. United States, 326 U.S. 455 (1946), the court refused to recognize transportation for celestial marriage purposes to be a violation of the act. The ostensible basis for the decision was the absence of the necessary physical restraint. However the court stated that the lidnaping lav was designed to assist the states in stamping out the sinister and growing menace of lidnaping. Chatwin v. United States, supra at 463. And it has been argued that the real basis of the decision was the Court's refusal to extend the Lindbergh Act beyond the menace of organized crime. 30 Mlins. L. KEv. 206 (1946). See Finley, The Lirdbcrgh Low, 28 GEo. L. J. 908 (1940). 
petitioner did not first seek relief in state courts. Exhaustion of state remedies is an essential preliminary to obtaining habeas corpus in federal courts. ${ }^{14}$

However dubious the court's legal conclusions, its desire to lend federal encouragement to the enforcement of established extradition procedure is praiseworthy. While the main purpose of extradition statutes is to aid law enforcement officials, ${ }^{15}$ these laws also provide basic safeguards for accused persons. An individual cannot be removed until his identity is established and it is shown that he is validly charged with crime, that he fled from justice, and that a proper demand has been made for his return. ${ }^{10} \mathrm{He}$ can test the proposed extradition by habeas corpus proceedings. ${ }^{\mathbf{1 7}}$ Moreover, extradition

14. 62 Stat. 967 (1948), 28 U.S.C. \$2254 (Supp. 1946); Darr v. Burford, 339 U.S. 200 (1949). See Miller, J., dissenting in Collins v. Frisbie, 189 F. 2d 464, 468 (6th Cir. 1951). Federal courts have disclaimed jurisdiction in extradition cases where the petitioner has not exhausted his asylum state remedies. Dye v. Johnson, 338 U.S. 864 (1949).

15. See Biddinger v. Commissioner, 245 U.S. 128 (1917); Appleyard v. Massachusetts, 203 U.S. 222, 227 (1906); Lascelles v. Georgia, 148 U.S. 537, 542 (1893).

16. 18 U.S.C. $\$ 3182$ (Supp. 1946). The Uniform Extradition Act also contains these requirements.

In addition, the demanding state must submit a copy of an indictment or affidavit macle before a magistrate charging the person with treason, felony or other crime. 18 U.S.C. $\S 3182$ (Supp. 1946). This is also required under the Uniform Act. For the technical content requirements of the papers, see Pierce v. Creecy, 210 U.S. 387 (1908); Hyatt v. Corkran, 188 U.S. 691 (1903); United States v. O'Brien, 138 F. 2d 217 (7th Cir. 1943). Any method presoribed by the demanding state for institution of a criminal procecding satisfies the quantum of proof required by the federal statute. Biddinger v. Commissioner, 245 U.S. 128 (1917) ; Ex parte Morgan, 78 F. Supp. 756, 761 (S.D. Cal. 1948), aff'l, 175 F. 2 d 404 (9th Cir. 1949).

The governor of the asylum state can issue a warrant for arrest only after considering the authenticity of the criminal charge. 18 U.S.C. $\$ 3182$ (Supp. 1946), Uniform Act $\$ \S 2,7$. For explicit statement of governors' duties see Graffenreid, The Law of E.ttradition, 2 ALA. L. Rev. 207 (1950). However under Uniform Act $\$ 13$, a person charged with a crime in another state can be arrested in the asylum state before the extradition requests are made. And $\S 14$ allows arrest without a warrant upon reasonable information that the accused stands charged in the courts of a state with a crime punishable by death or imprisonment for a term exceeding one year.

17. Although the constitutional extradition clause and its enabling statutes do not provide for habeas corpus proceedings, this ancient common law right was early applicd to rendition procedures. See Roberts v. Reilly, 116 U.S. 80 (1885). See also Uniform Act $\S 10$ which provides for habeas corpus in the state courts. In habeas corpus proceedings the question is whether the legal extradition requirements have been mot and not whether the accused is guilty or innocent. E.g., Whitaker v. Hitt, 285 Fed. 797 (D.C. Cir. 1922) ; Kingsbury's Case, 106 Mass. 223 (1870); Uniform Act $\$ 20$. The court may consider whether the accused is charged with a crime against the laws of the demanding state. E.g., Commonwealth v. Hare, $36 \mathrm{~Pa}$. Super. 125, 130 (1908). And it may also determine if the accused is actually the individual wanted. Uniform Act $\$ 20$ (allows guilt or innocence to be looked into to determine the identity of the person); sec Letwick v. State, 211 Ark. 1, 4, 198 S.W. 2d 830, 831 (1947).

Several recent decisions have granted substantive safeguards. Upon proof of certain kinds of deprivation of constitutional rights by the demanding state, the defendant must be freed by the courts in the asylum state upon habeas corpus. Commonwealth $c \cdot x r c$. Mattox v. Superintendent, $152 \mathrm{~Pa}$. Super. 167, 31 A. 2d 576 (1943) (lynching); John- 
requires action by the refuge state's governor. ${ }^{18}$ If he believes that the extraditing state may deprive the accused of constitutional rights, the governor has an opportunity to grant asylum by refusing to act. ${ }^{10}$ Requiring observance of statutory procedure should also tend to minimize possible police brutality incident to returning a fugitive. Unlawful seizure and abduction by officials acting beyond their jurisdiction, if condoned by courts, is likely to result in violence as it did in Collins' case.

Since the Sixth Circuit's attempt to enforce compliance with the extradition statute is unlikely to be upheld, a legislative solution is necessary. Congress should amend the extradition statute to provide that violation of its provisions deprives the extraditing state's courts of jurisdiction to try the accused. ${ }^{-9}$ Defendants could invoke this statute at trial, or in habeas proceedings."2 Congress should also enact suitable penalities for officers who disregard the law. ${ }^{22}$

son v. Dye, 175 F. 2d 250 (3rd Cir. 1949) (cruel and unusual punishment-chain gang; reversed by United States Supreme Court, 338 U.S. 864 (1949) on non-exshaustion of state remedy theory). But cf. Johnson v. Mathews, 182 F.2d 677 (D.C. Cir. 1950), cerf. denied, 340 U.S. 828 (1950).

For general historical background of individual rights in interstate rendition see Hoague, Extradition Betrieen States, 13 Axr. L. Rev. 181 (1879).

18. See Graffenreid, supra note 16.

19. Kentucky v. Dennison, 24 How. 66 (U.S. 1851) held that the federal extradition statutes do not provide any means to compel a governor of an asylum state to extradite. And in dicta the Court also stated the constitutional clause itself did not permit such compulsion. Federal courts have followed this decision and ruled that no power of the federal government presently exists to compel extradition by a state. Sec c.g., Applieation of Mriddlebrooks, 88 F. Supp. 943, 952 (S.D. Cal. 1950). Since the federal estradition statute has not been changed since the Demison decision, the issue of whether the Constitution gives the government power to compel extradition has never actually been before the courts. And where the extradition requirements have been violated, the prisoner, once in the demanding state, can claim no federal right. E.g., Mahon v. Justice, 127 U.S. 700 (1S8S) (since federal law makes no provision for the return of an illegally seized person, he cannot claim release; nor does he have any right of asylum in the state to which he has fled).

20. This action might be taken under the commerce clause. It has been held that transportation of people across state lines is commerce. Edwards v. California, 314 U.S. 160,172 (1941). And Congress has already enacted legislation under the commerce clause making it a federal offense to move in interstate commerce for the purpose of avoiding prosecution or confinement after conviction for certain enumerated crimes under the laws of the place from which one has fled. Fugitive Felon Act, 18 U.S.C. $\$ 1073$ (Supp. 1946); Simmons v. Zerbst, 18 F. Supp. 929 (N.D. Ga. 1937); United States v. Miller, 17 F. Supp. 65 (W.D. Ky. 1936).

21. Lack of jurisdiction has traditionally been a basis for release at any time. MrcClaughry v. Deming, 186 U.S. 49 (1902); In re Shull, 221 Mio. 623, 121 S.W. 10 (1909).

22. Cf. Uniform Act $\$ 11$ declaring that an officer of the asylum state who wilfully deprives an accused of the rights enunciated in $\S 10$ is guilty of a misdemeanor and is subject to penal fine or sentence. The fine cannot exceed $\$ 1000.00$ nor the sentence 6 months. Curiously enough, no penalty provision is made for officers of the trial state who deprive the accused of his rights in another state. 
Freeing accused persons who were illegally extradited need not defent the state's legitimate interest in prosecuting and convicting the guilty. The individual released on habeas corpus could be retried and reconvicted, after being properly extradited. ${ }^{23}$ However, existing extradition procedures fail to provide machinery to return an accused to an asylum state so that he can be lawfully extradited. ${ }^{24}$ Since the illegality of the original removal persists until the defendant is properly extradited, he might at present secure permanent immunity from trial simply by refusing to leave the trying state. Such permanent immunity for defendants would be a high price to pay for encouraging compliance with extradition requirements. But legislation could prevent this possibility. If the accused remains in the state for an unreasonable period of time, he should be deemed to have waived the abduction defense. ${ }^{25}$ State officers could then validly rearrest him. Such an amendment, together with the other legislation proposed, would guarantee observance of extradition procedures without hampering law enforcement.

23. Courts generally hold that a defendant released on his own motion cannot claim that jeopardy attached to the first proceedings. Hence the person is deemed to bave waived the plea of double jeopardy in a second trial. E.g., Stroud v. United States, 251 U.S. 15 (1919) ; Murphy v. Massachusetts, 177 U.S. 155 (1900); United States v. Lowrey, 77 F. Supp. 301 (W.D. Pa. 1948).

Some courts, however, hold that if a person is freed on habeas corpus double jeopardy attaches to a new trial if the original trial court had jurisdiction when the trial started. People ex rel. Meyer v. Warden, 269 N.Y. 426, 199 N.E. 647 (1936). But it is universally held that where the trial court had absolutely no jurisdiction, double jeopardy cannot be pleaded to a new indictment. Mitchell v. Youell, 130 F. 2d 880 (4th Cir. 1942); Ogle v. State, 43 Tex. Crim. Rep. 219, 63 S.W. 1009 (1901) ; State v. Odell, 4 Blackf. 156 (Ind. 1836).

24. Lack of statutory authority to return an illegally extradited defendant to the asylum state has motivated courts in refusing to recognize illegal abduction as a barricr to trial. See Mahon v. Justice, 127 U.S. 700 (1888). And this possibility is a genuine fear of the states. See Brief and Argument for Writ of Certiorari, Frisbie v. Collins, U.S. Supreme Court 12-3 (October 1951).

25. To achieve national uniformity, Congress could prescribe that an illegally cxtradited person should be given a reasonable time to return to the asylum state. Failure to return within this period could be deemed a waiver of the defendants' federal right. The state civil immunity statute prescribing reasonable time for return of a witness could be a guide for federal action. Uniform Act to Secure the Attendance of Witnesses From Without a State in Griminal Proceedings, 9 UNIF. LAws ANN. 37 (1951).

There is a valid precedent for enacting legislation to permit the accused a reasonable time to return to the asylum state. The Uniform Extradition Act stipulates that a person brought into the state to face a criminal charge is immune from civil process until convicted or, if acquitted, until he has had a reasonable time to return to the asylum state from which he was extradited. Uniform Act \$25.

Cf. the general common law rule that a non-resident entering a state to respond to a criminal indictment is entitled to exemption from service of process in a civil case while coming and going without unnecessary delay by the usual routes of travel. Church v. Church, 270 Fed. 361 (D.C. Cir. 1921); See also Kaufman v. Garner, 173 Fed. 550, 554 (C.C. W.D. Ky. 1909); Murray v. Wilcox, 122 Iowa 188, 97 N.W. 1087 (1904). 